\title{
Megaloblastic erythropoiesis and macrocytosis in patients on anticonvulsants
}

\author{
S N WICKRAMASINGHE， GAIL WILLIAMS， JUDITH SAUNDERS， J H J DURSTON
}

British Medical fournal, 1975, 4, 136-137

\section{Summary}

The results of deoxyuridine suppression tests on the bone marrow cells of 14 patients on anticonvulsant drugs, 11 of whom had evidence of megaloblastic erythropoiesis, indicated that the megaloblastic changes and macrocytosis encountered in treated epileptics are often not caused either by folate deficiency or by drug-induced impairment of the 5, 10-methylenetetrahydrofolatedependent methylation of deoxyuridylate to thymidylate. A folate-related abnormality in the methylation of deoxyuridylate was found in only two of the 11 patients with megaloblastic erythropoiesis.

\section{Introduction}

Some patients treated with one or more of the three standard anticonvulsant drugs (phenytoin sodium, phenobarbitone, and primidone) develop a macrocytosis. The incidence of macrocytosis in non-anaemic patients has been estimated to be between $8 \%$ and $28 \%{ }_{0} .^{1-3}$

Reynolds et al ${ }^{+}$studied 45 non-anaemic epileptics receiving phenytoin sodium together with either phenobarbitone or phenobarbitone and primidone and found that $17\left(38^{\circ}{ }_{0}\right)$ of them showed megaloblastic haemopoiesis. Only five of the patients with megaloblastic marrows were thought to have macrocytosis, and a few with macrocytosis were considered to have normoblastic marrows. Furthermore, although $39\left(81^{\circ}{ }_{0}\right)$ of the patients had subnormal serum folate levels, the incidence of low serum folate levels was similar in the normoblastic and megaloblastic groups. In view of this report of a poor correlation between macrocytosis, low serum folate levels, and megaloblastic change it appeared that folate deficiency might not necessarily be responsible for the macrocytosis encountered in all patients on anticonvulsant treatment. We therefore performed deoxyuridine suppression tests on the bone marrow cells of 14 patients on anticonvulsant drugs. This test, which is designed to detect an abnormality in the conversion of deoxyuridylate to thymidylate, is a sensitive method of diagnosing vitamin $\mathrm{B}_{12}$ or folate deficiency at the cellular level. ${ }^{j-i}$

\section{Patients and methods}

Fourteen patients with epilepsy were studied (table I). All but one were receiving phenytoin sodium together in some cases with one or more other anticonvulsant drugs. None were consuming excessive amounts of alcohol.

Blood counts were performed on a Coulter counter (model S), and red cell folate and serum vitamin $B_{12}$ levels were measured by standard microbiological assay techniques using Lactobacillus case and $L$ leichmanni respectively. The morphology of the marrow cells

Department of Haematology and the MRC Experimental Haematology Unit, St Mary's Hospital Medical School, London W2 1 PG $S \mathrm{~N}$ WICKRAMASINGHE, MB, PHD, senior lecturer in haematology GAIL WILLIAMS, MB, BS, lecturer in haematology JUDITH SAUNDERS, junior technical officer

Department of Neurology, St Mary's Hospital, London W2 1PG

J H J DURSTON, MB, MRCP, senior registrar in neurology (now consultant neurologist, Whittington Hospital, London N19 5NF)
TABLE I-Age and sex of patients and nature of drug treatment

\begin{tabular}{|c|c|c|c|c|c|c|}
\hline \multirow{2}{*}{$\begin{array}{l}\text { Case } \\
\text { No }\end{array}$} & \multirow[t]{2}{*}{ Sex } & \multirow{2}{*}{$\begin{array}{c}\text { Age } \\
\text { (years) }\end{array}$} & \multicolumn{3}{|c|}{$\begin{array}{c}\text { Duration of current drug treatment } \\
\text { (years) }\end{array}$} & \multirow{2}{*}{$\begin{array}{l}\text { Other } \\
\text { anticonvulsant } \\
\text { drugs }\end{array}$} \\
\hline & & & $\begin{array}{l}\text { Pheno- } \\
\text { barbitone }\end{array}$ & Phenytoin & Primidone & \\
\hline $\begin{array}{r}1 \\
2 \\
3 \\
4 \\
5 \\
6 \\
7 \\
8 \\
9 \\
10 \\
11 \\
12 \\
13 \\
14\end{array}$ & $\begin{array}{l}\mathrm{F} \\
\mathrm{F} \\
\mathrm{M} \\
\mathrm{F} \\
\mathrm{F} \\
\mathrm{F} \\
\mathrm{F} \\
\mathrm{M} \\
\mathrm{F} \\
\mathrm{M} \\
\mathrm{F} \\
\mathrm{F} \\
\mathrm{F} \\
\mathrm{F}\end{array}$ & $\begin{array}{l}38 \\
37 \\
39 \\
65 \\
34 \\
76 \\
67 \\
52 \\
78 \\
60 \\
54 \\
27 \\
52 \\
38\end{array}$ & $\begin{array}{l}2 \\
6 \\
3\end{array}$ & $\begin{array}{c}12 \\
2 \\
6 \\
3 \\
8 \\
30 \\
9 \\
11 \\
0 \cdot 2 \\
3 \\
20 \\
5 \\
5\end{array}$ & $\begin{array}{l}3 \\
5\end{array}$ & $\begin{array}{c}\text { Sulthiame } \\
\text { Methsuximide }\end{array}$ \\
\hline
\end{tabular}

TABLE II-Haematological data

\begin{tabular}{|c|c|c|c|c|c|c|}
\hline $\begin{array}{l}\text { Case } \\
\text { No }\end{array}$ & $\underset{(\mathrm{g} / \mathrm{dl})}{\mathrm{Hb}}$ & $\underset{(\mathrm{f})}{\mathrm{MCV}}$ & $\begin{array}{c}\text { Red cell } \\
\text { folate } \\
(\mu \mathrm{g} / 1)\end{array}$ & $\begin{array}{c}\text { Serum } \\
\text { vitamin } \\
\mathbf{B}_{1: 2} \\
(\mathrm{ng} / 1)\end{array}$ & Bone marrow & $\begin{array}{c}\text { Deoxyuridine } \\
\text { suppressed } \\
\text { value } \\
\left({ }^{\circ}(1)\right.\end{array}$ \\
\hline $\begin{array}{l}1 \\
2\end{array}$ & $\begin{array}{l}10.0 \\
14.3\end{array}$ & $\begin{array}{l}73 \\
87\end{array}$ & $\begin{array}{r}206 \\
93\end{array}$ & 420 & $\begin{array}{l}\text { Micronormoblastic } \\
\text { Mildly } \\
\text { megaloblastic }\end{array}$ & $\begin{array}{l}6 \cdot 0 \\
7 \cdot 0\end{array}$ \\
\hline $\begin{array}{l}3 \\
4\end{array}$ & $\begin{array}{l}15 \cdot 4 \\
12 \cdot 2\end{array}$ & $\begin{array}{l}91 \\
92\end{array}$ & $\begin{array}{l}278 \\
168\end{array}$ & $\begin{array}{l}430 \\
570\end{array}$ & $\begin{array}{l}\text { Normoblastic } \\
\text { Mildly }\end{array}$ & $\begin{array}{l}1.0 \\
4 \cdot 3\end{array}$ \\
\hline $\begin{array}{l}5 \\
6\end{array}$ & $\begin{array}{l}12.9 \\
12.5\end{array}$ & $\begin{array}{l}93 \\
96\end{array}$ & $\begin{array}{l}200 \\
100\end{array}$ & 325 & $\begin{array}{l}\text { Normoblastic } \\
\text { Mildly } \\
\text { megaloblastic }\end{array}$ & $\begin{array}{l}4 \cdot 8 \\
4 \cdot 1\end{array}$ \\
\hline $\begin{array}{l}7 \\
8\end{array}$ & $\begin{array}{l}14 \cdot 1 \\
14 \cdot 3\end{array}$ & $\begin{array}{l}96 \\
96\end{array}$ & $\begin{array}{l}183 \\
143\end{array}$ & $\begin{array}{l}350 \\
750\end{array}$ & $\begin{array}{l}\text { Megaloblastic } \\
\text { Mildly } \\
\text { megaloblastic }\end{array}$ & $\begin{array}{l}6 \cdot 3 \\
4 \cdot 6\end{array}$ \\
\hline $\begin{array}{l}9 \\
10 \\
11 \\
12 \\
13 \\
13 * \\
14\end{array}$ & $\begin{array}{r}13.2 \\
13.4 \\
12.9 \\
13.8 \\
4.7 \\
7.0 \\
13.3\end{array}$ & $\begin{array}{r}100 \\
100 \\
102 \\
104 \\
106 \\
78 \\
110\end{array}$ & $\begin{array}{r}270 \\
176 \\
31 \\
305 \\
98 \\
63\end{array}$ & $\begin{array}{r}1000 \\
660 \\
160 \\
750 \\
295 \\
\\
260\end{array}$ & $\begin{array}{l}\text { Megaloblastic } \\
\text { Megaloblastic } \\
\text { Megaloblastic } \\
\text { Megaloblastic } \\
\text { Megaloblastic } \\
\text { Micronormoblastic } \\
\text { Megaloblastic }\end{array}$ & $\begin{array}{c}3 \cdot 4 \\
6 \cdot 5 \\
17 \cdot 5 \\
6 \cdot 6 \\
14 \cdot 4+ \\
8 \cdot 1 \\
6 \cdot 1\end{array}$ \\
\hline $\begin{array}{l}\text { Normal } \\
\text { values }\end{array}$ & & $82 \cdot 0-97 \cdot 1$ & $100-450$ & $150-850$ & & $5 \cdot 37 \pm 3 \cdot 88_{+}+$ \\
\hline
\end{tabular}

*Investigations repeated after taking normal diet for one month.

+ Abnormal deoxyuridine suppressed value was partially corrected (to $10^{\prime \prime}{ }_{10}$ ) by addition of 10 ug pteroylglutamic acid per $\mathrm{ml}$ of marrow culture.

$+2 \mathrm{SD}$

Conversion: SI to traditional units
MCV: $1 \mathrm{fl}=1 \mu \mathrm{m} .^{3}$ Folate: $1 \mu \mathrm{g} l=1 \mathrm{ng} \mathrm{ml}$. Vitamin $\mathrm{B}_{12}: 1 \mathrm{ng} / \mathrm{l}=1 \mathrm{pg} / \mathrm{ml}$

was assessed independently by two observers. Erythropoiesis was considered to be megaloblastic whenever there was dissociation between nuclear and cytoplasmic maturation at the early polychromatic erythroblast stage. The deoxyuridine suppression test was performed on freshly aspirated marrow. ${ }^{67}$ The test was repeated in case 13 after an interval of one month during which the patient, who had been on an inadequate diet, was given a normal diet.

\section{Results}

Six of the patients had high mean cell volumes (MCV), 11 (including the six with high MCVs) had megaloblastic changes in their bone marrow, and four (three with high MCVs and one with a normal MCV) had low red cell folate levels (table II). The results of the deoxyuridine suppression tests were normal in all but two patients (cases 11 and 13) (table II). In case 13, after maintenance on a normal diet for one month the previously raised $\mathrm{MCV}$ became subnormal, erythropoiesis became micronormoblastic, and the results of the deoxyuridine suppression test returned to normal. In case 13 but not in case 11 the abnormal deoxyuridine suppressed value was partially corrected by the addition of $10 \mu \mathrm{g}$ pteroylglutamic acid per $\mathrm{ml}$ of marrow culture. 


\section{Discussion}

Because some patients on anticonvulsant drugs have low levels of serum folate ${ }^{128}$ and red cell folate ${ }^{9}$ most investigators have assumed that the macrocytosis that may develop in such patients is caused either by folate deficiency or by some interference with folate metabolism. The mechanisms that have been proposed to explain the low serum and red cell folate levels include $(a)$ an inadequate dietary intake of folate compounds, (b) an impaired absorption of folate monoglutamate from the diet, ${ }^{1-1: 2}$ (c) an impaired absorption of dietary folate polyglutamate as a consequence of the inhibition of folate conjugase by the $\operatorname{drug}(\mathrm{s}),{ }^{13 \cdot 15}$ (d) displacement of folate compounds from their carrier plasma proteins by the $\operatorname{drug}(\mathrm{s}),{ }^{*}(e)$ interference with the formation and function of intracellular folate coenzymes as a result of a structural similarity between folate coenzymes and anticonvulsant drugs, ${ }^{116}$ and $(f)$ increased utilisation of folate in the liver as a consequence of the involement of folate coenzymes in the detoxification of anticonvulsant drugs. ${ }^{9}$

Nine of the treated epileptics with megaloblastic erythropoiesis studied by us (including four patients with high MCVs) gave normal results in the deoxyuridine suppression test. Therefore, neither folate deficiency nor an interference with the 5,10 methylenetetrahydrofolate-dependent methylation of deoxyuridylate to thymidylate could be implicated in the pathogenesis of the macrocytosis and megaloblastic changes in these nine patients.

The results in cases 11 and 13 indicate that the bone marrow cells of some patients on anticonvulsant drugs do suffer from an abnormality in the methylation of deoxyuridylate. In case 13 this abnormality was partially corrected by the addition of $10 \mu \mathrm{g}$ pteroylglutamic acid per $\mathrm{ml}$ of marrow culture. As this concentration of pteroylglutamic acid corrects the abnormal deoxyuridine suppressed value in folate-deficient patients, ' and as the bone marrow cells in case 13 gave a normal deoxyuridine suppressed value after one month on an improved diet, it is likely that the abnormality in the methylation of deoxyuridylate detected in this case was caused by a dietary folate deficiency. The addition of $10 \mu \mathrm{g}$ pteroylglutamic acid per $\mathrm{ml}$ of marrow culture did not correct the abnormal deoxyuridine suppressed value in case 11, suggesting the possibility of some drug-induced interference with the methylation of deoxyuridylate. The elucidation of the mechanisms underlying the abnormal deoxyuridine suppressed values that are occasionally encountered in patients on antiepileptic drugs will require a study of a much larger group of treated epileptics.

The two patients giving abnormal results in the deoxyuridine suppression test had low red cell folate levels. Two other patients with low red cell folate levels (cases 2 and 14), however, gave normal results in the test. This discrepancy is reminiscent of the previously reported failure of most treated epileptics with low serum folate levels to excrete abnormal amounts of formiminoglutamic acid (figlu) in their urine after a loading dose of histidine. ${ }^{+17}$ Apparently the two folate-dependent metabolic steps investigated by the deoxyuridine suppression test and the figlu excretion test are sometimes unimpaired in treated epileptics, even when their serum and red cell folate levels have fallen below normal. The explanation for this is uncertain.

The megaloblastic changes and macrocytosis in patients giving normal results in the deoxyuridine suppression test are presumably caused by a direct effect of the anticonvulsant drugs or their metabolites on some biochemical step(s) other than the conversion of deoxyuridylate to thymidylate.

We thank Dr C H Edwards and Sir Roger Bannister for permission to study patients under their care.

\section{References}

${ }^{1}$ Hawkins, C F, and Meynell, M J, Quarterly fournal of Medicine, 1958, 27, 45.

2 Malpas, J S, Spray, G H, and Witts, L J, British Medical Fournal, 1966, $1,955$.

${ }^{3}$ Child, J A, Khattak, B Z, and Knowles, J P, British fournal of Haematology, 1969, 16, 451.

4 Reynolds, E H, et al, Quarterly fournal of Medicine, 1966, 35, 521.

${ }^{5}$ Herbert, V, et al, British fournal of Haematology, 1973, 24, 713.

${ }^{6}$ Wickramasinghe, S N, and Longland, J E, British Medical fournal, 1974, 3 148.

Wickramasinghe, S N, and Saunders, J E, British Medical Fournal, 1975, 2,87

${ }^{8}$ Klipstein, F A, Blood, 1964, 23, 68

${ }^{9}$ Maxwell, J D, et al, British Medical fournal, 1972, 1, 297.

10 Meynell, M J, Lancet, 1966, 1, 487.

${ }^{11}$ Benn, A, et al, British Medical fournal, 1971, 1, 148.

1. Doe, W F, et al, British Medical fournal, 1971, 1, 669.

${ }_{13}$ Rosenberg, I H, et al, Lancet, 1968, 2, 530.

${ }^{14}$ Hoffbrand, A V, and Necheles, T F, Lancet, 1968, 2, 528.

15 Baugh, C M, and Krumdieck, C L, Lancet, 1969, 2, 519.

${ }^{16}$ Girdwood, R H, and Lenman, J A R, British Medical fournal, 1956, 1, 146.

17 Jensen, O N, and Olesen, O V, Archives of Neurology, 1969, 21, 208.

\title{
Continuous positive airway pressure and mechanical ventilation by facemask in newborn infants
}

\author{
L P ALLEN, A M BLAKE, G M DURBIN D INGRAM, E O R REYNOLDS, \\ $P$ D WIMBERLEY
}

British Medical fournal, 1975, 4, 137-139

\section{Summary}

During a nine-month period 24 newborn infants were treated with continuous positive airway pressure (CPAP)

University College Hospital and Medical School, London WC1

L P ALLEN, B SC, research student in medical physics

A $M$ BLAKE, RSCN, paediatric nursing officer

G M DURBIN, MRCP, lecturer in paediatrics

D INGRAM, BA, senior physicist

E O R REYNOLDS, FRCP, consultant paediatrician

P D WIMBERLEY, MRCP, senior paediatric registrar or mechanical ventilation delivered through a facemask. The mask was held in place in a way that minimised trauma and distortion of the head. The median birth weight of the infants was $1096 \mathrm{~g}$ and their median gestational age 29 weeks. The usual reason for treatment was hyaline membrane disease or recurrent apnoea due to inadequate control of breathing. Twenty-one of the infants survived. The technique was simple to apply and complications were minimal. We suggest that it may have advantages over other methods of applying CPAP or mechanical ventilation to infants mildly affected by respiratory illnesses and that it should be useful in avoiding endotracheal intubation or reducing the length of time that infants with more serious illnesses are intubated. 